\title{
IS OCYPODE QUADRATA (FABRICIUS, 1787) A USEFUL TOOL FOR EXPOSED SANDY BEACHES MANAGEMENT IN BAHIA STATE (NORTHEAST BRAZIL)?
}

\author{
Wagner Ferreira Magalhães ${ }^{1}$; Juliana Barbosa Lima ${ }^{2}$; Francisco Barros ${ }^{1}$ and José Maria Landim Dominguez $z^{3}$ \\ ${ }^{1}$ Universidade Federal da Bahia - Instituto de Biologia \\ Departamento de Zoologia - Laboratório de Ecologia Bentônica \\ (Campus Ondina, 40170-280 Salvador, BA, Brasil) \\ wagnerm@ufba.br; barrosf@ufba.br \\ ${ }^{2}$ Universidade Federal da Bahia - Instituto de Geociências \\ lima.julianab@gmail.com \\ ${ }^{3}$ Universidade Federal da Bahia - Instituto de Geociências \\ landim@ufba.br
}

\begin{abstract}
Despite the existing proposals for sustainable use of the Brazilian coast, there are few mechanisms for quantification and qualification of anthropogenic impacts. For instance, the Projeto Orla (MMA, 2006) defines typologies of coastline classification, taking into account aspects of the landscape such as originality, human population density and levels of occupation. Nevertheless, the effects of urbanization on resident biota are not considered in this classification. Furthermore, there is a need for studies to validate the use of biological indicators that take into account the spatial and temporal variation of the biota, so as to arrive at a complete assessment of the urbanization impacts on exposed sandy beach.
\end{abstract}

The genus Ocypode is a well known and conspicuous inhabitant of tropical and sub-tropical sandy beaches worldwide (BROWN; MCLACHLAN, 1990) and Ocypode quadrata, the unique species of this genus in Brazil, is commonly found in Brazilian sandy beaches, distributed from the states of Pará to Rio Grande do Sul (MELO, 1996), including estuarine beaches (TURRA et al., 2005; ROSA; BORZONE 2008). There is increasing evidence that this species is negatively affected by human disturbance (e.g. BLANKENSTEYN, 2006; NEVES et al., 2006) and that comparison of burrow counts among beaches that differ in human impact intensity is a useful approach for beach characterization (e.g. BARROS, 2001). The objective of the present study, with a view to contributing to the development of management strategies for Brazilian sandy beaches, is to test the applicability of the Ocypode quadrata in the classification of exposed sandy beaches on the Bahia coast subject to different degrees of urbanization.

Field work was conducted on three days (October 2007) on nine exposed sandy beaches on the north coast of Bahia (Fig. 1). The selection of the sandy beaches was based on Projeto Orla criteria (MMA, 2006), according to which (i) "urban beaches" (Barra, Corsário and Jardim de Alah - Fig I) have medium to high density of buildings and resident populations, urbanized landscapes and high level of pollution (visual, aesthetic and noise); (ii) "Moderately urban beaches" (Catussaba, Villas do Atlântico and Arembepe - Fig. 1) have low to medium density of buildings and resident populations, with signs of recent human occupation, partly urbanized landscape and medium potential for pollution, and (iii) "nonurban beaches" (Busca Vida, Jacuípe and Scar Reef Fig. 1) have very low resident population, landscapes with a high degree of originality and small potential for pollution. Further, all the beaches studied are of the intermediate morphodynamic stage (CARVALHO 2002; MMA 2003)

On each beach, two transects longitudinal to the shore were randomly sampled at the frontal dune and supralitoral region in areas without commercial beach tents and the number of burrows was counted in 60 quadrates $\left(1 \mathrm{~m}^{2}\right)$. To test the differences in number of burrows between urbanization categories of beaches and beach heights an analysis of variance (ANOVA) was carried out with two fixed factors: urbanization (of three levels: urban, moderately urban and nonurban) and beach height (of two levels: frontal dune and supralitoral). All data were square root $(x+1)$ transformed and found to be homogeneous at $\mathrm{p}>0.05$ using Cochran's C-test (UNDERWOOD, 1981). Multiple comparisons among the means were made using the Student-Newman-Keuls (SNK) test.

A total of 1283 burrows were counted and most (more than $50 \%$ ) of them were found on nonurban beaches ( $\mathrm{n}=723$ burrows). Only on Barra Beach no burrows were found on the supralitoral and on all the beaches greater numbers of burrows were found on the frontal dunes than in the supralitoral zones (Fig. 2). 


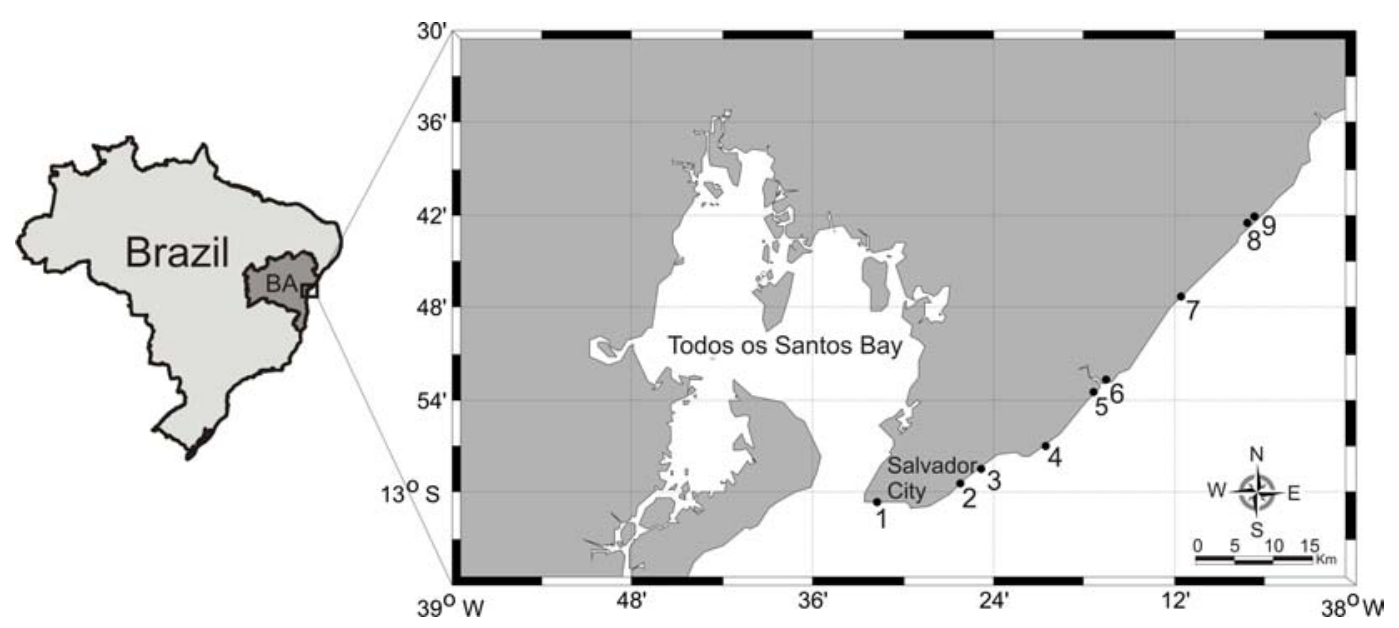

Fig. 1. Map showing the sandy beaches sampled (Urban beaches: 1- Barra; 2- Jardim de Alah and 3- Corsário; Moderately urban beaches: 4- Catussaba, 5- Villas do Atlântico and 7- Arembepe; Non-urban beaches: 6- Busca Vida; 8- Jacuípe and 9- Scar Reef).

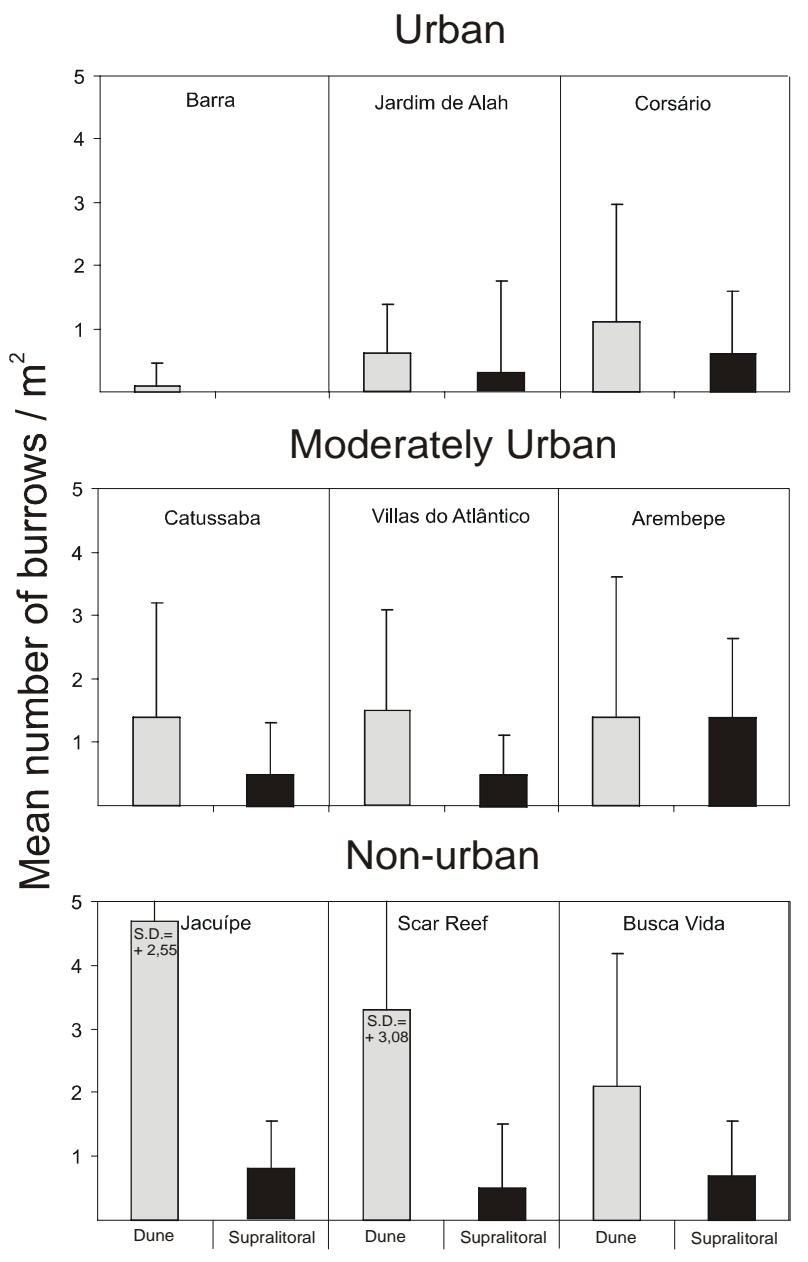

Fig. 2. Mean (+ S.D.) number of burrows per square meter at each beach height (Supralitoral and Dune $)(\mathrm{n}=60)$. 
In general, the number of burrows was smaller on urban than on moderately urban and nonurban beaches. The burrows found on the supralitoral level of Scar Reef Beach (a non-urban beach, $\mathrm{n}=31$ ) were comparable in number with the results from urban beaches (Corsário Beach, $\mathrm{n}=36$ ). These results might reflect the negative impact of the continuous traffic of off-road vehicles especially on weekends, which could considerably reduce the density of crabs observed. Steiner and Leatherman (1981) found that areas subject to off-road vehicle traffic had significantly lower densities of Ocypode burrows than did the undisturbed areas or areas with pedestrian traffic only. A similar relationship between the observed densities of Ocypode burrows and off-road vehicles had been noted by Wolcott ; Wolcott (1984), Schlacher and Thompson (2007), Schlacher et al. (2007) and Hobbs et al. (2008). These results indicate that there is a need of better methods for the classification of exposed sandy beaches, which should include environmental health and biological aspects.

ANOVA results (Table 1) showed that there were significant differences between beaches with different degrees of urbanization and between beach heights.

Table 1. ANOVA results. Degree of urbanization and beach height were used as factors and burrow density as variable. Differences are significant at $\mathrm{p}<0.05$.

\begin{tabular}{lcccc}
\hline \multicolumn{1}{c}{ Source of variation } & d.f. & Mean Square & $F$ & $P$ \\
\hline Urbanization (Urb) & 2 & 46.14 & 10.3 & 0.0025 \\
Beach Height (BeH) & 1 & 74.87 & 16.72 & 0.0015 \\
Urb X BeH & 2 & 14.9 & 3.33 & 0.0709 \\
\hline
\end{tabular}

The a posteriori test (SNK) showed that there were no significant differences between moderately urban and non-urban beaches, however, it showed significantly smaller numbers of burrows on urban beaches than on those of the other two categories. Moderately urbanized beaches showed intermediate characteristics and evidence of recent occupation. Catussaba, Villas do Atlântico and Arembepe beaches, although fairly frequently occupied by beach users, have a well-preserved small frontal dune zone with vegetation (e.g. Ipomea spp). Even though the urban beaches of Corsário and Jardim de Allah had preserved frontal dunes, they have an adjacent concrete wall. Barra Beach did not have a frontal dune zone with the typical vegetation of this ecosystem and presented the lowest number of burrows.

The beach height sampled among the urbanized categories also showed significant differences. A behavioral characteristic of this species is the use of the frontal dune area as a habitat (e.g. VELLOSO et al., 1997). Even though a high variation in burrow numbers was found along the transects, the
ANOVA did not show any significant interaction between beach height and degree of urbanization, probably because the degree of urbanization may not affect the $O$. quadrata preference for frontal dune habitation.

Our results are in agreement with those of Barros (2001), Blankesteyn (2006) and Neves et al. (2006) who have shown that the density of Ocypode spp burrows is significantly lower on urban beaches than on non-urban beaches and have also highlighted that these species could be used as biological indicators for detecting human impacts on exposed sandy beaches. Moreover, considering the importance of the frontal dune zone as a habitat for O. quadrata, the human occupation of this geomorphological feature should be approached with caution and constructions should only be permitted at a certain distance inland from the sandy frontal dune area.

The Projeto Orla could also include biological criteria for the classification of sandy beaches so as to contribute to the establishment of more adequate management strategies. $O$. quadrata provides an accurate picture of anthropogenic impacts on exposed sandy beaches and should complement the criteria already in use. However, there is a need for further studies on the biology of this species to complement the existing ones (e.g. ALBERTO; FONTOURA, 1999; NEGREIROS-FRANSOZO et al., 2002) and to elucidate those as yet unexplained temporal and spatial aspects of the Brazilian coast. If these proposals were to be implemented, then a more complete scheme for Brazilian sandy beaches management could be developed.

\section{ACKNOWLEDGEMENTS}

The authors are grateful to Ana Paula Figueiredo, Anne Nascimento and Ricardo Domingues for their field assistance.

\section{REFERENCES}

ALBERTO, R. M. F.; FONTOURA, N. F. Distribuição e estrutura etária de Ocypode quadrata (Fabricius, 1787) (Crustacea, Decapoda, Ocypodidae) em praia arenosa do litoral sul do Brasil. Ver. Bras. Biol., v. 59, n. 1, p. 95$108,1999$.

BARROS, F. Ghost crabs as a tool for a rapid assessment of human impacts on exposed sandy beaches. Biol. Conserv., v. 97, n. 3, p. 399-404, 2001.

BLANKENSTEYN, A. O uso do caranguejo maria-farinha Ocypode quadrata (Fabricius) (Crustacea, Ocypodidae) como indicador de impactos antropogênicos em praias arenosas da Ilha de Santa Catarina, Santa Catarina, Brasil. Rev. Bras. Zool., v. 23, p. 870-876, 2006. 
BROWN, C.; MCLACHLAN, A. Ecology of sandy shores. Amsterdam: Elsevier, 1990. 290 p.

CARVALHO, M. P. Fatores meteorológicos, oceanográficos, morfodinâmicos, geológicos e urbanos relacionados à incidência de afogamentos na costa Atlântica de Salvador. 167 p. Master's thesis, Universidade Federal da Bahia, Salvador, 2002.

HOBBS, C.H.; LANDRY, C.B. \& PERRY, J.E. Assessing Anthropogenic and Natural Impacts on Ghost Crabs (Ocypode quadrata) at Cape Hatteras National Seashore, North Carolina. J. Coast. Res., v. 24, n. 6, p. 1450-1458, 2008.

MMA. Ministério do Meio Ambiente. (Brasil). Projeto Orla: Manual de Gestão. Ministério do Meio Ambiente; Ministério do Planejamento, Orçamento e Gestão. - Brasília, DF, 2006. 88 p

MMA. Ministério do Meio Ambiente. (Brasil). Diagnóstico oceanográfico e proposição de disciplinamento de usos da faixa marinha do litoral norte do Estado da Bahia. Ministério do Meio Ambiente; Governo do Estado da Bahia, Secretaria do Meio Ambiente e Recursos Hídricos, Centro de Recursos Ambientais. Salvador, 2003. $128 \mathrm{p}$.

MELO, G. A. S. Manual de identificação dos Brachyura (caranguejos e siris) do litoral brasileiro. São Paulo: FAPESP; Ed. Plêiade, 1996. 603 p.

NEGREIROS-FRANSOZO, M. L.; FRANSOZO, A.; BERTINI, G. Reproductive cycle and recruitment period of Ocypode quadrata (Decapoda, Ocypodidae) at a sandy beach in southeastern Brazil. J. crustacean Biol., v. 22, n. 1, p. 157-161, 2002.

NEVES, F. M.; BEMVENUTI, C. E. The ghost crab Ocypode quadrata (Fabricius, 1787) as a potential indicator of anthropic impact along the Rio Grande do Sul coast, Brazil. Biol. Conserv., v. 133, p. 431-435, 2006.
ROSA, L. C. DA; BORZONE, C. A. Spatial distribution of the Ocypode quadrata (Crustacea: Ocypodidae) along estuarine environments in the Paranaguá Bay Complex, southern Brazil. Rev. Bras. Zool., v. 25, n. 3, p. 383$388,2008$.

SCHLACHER, T. A.; THOMPSON, L. Exposure of fauna to off-road vehicle (ORV) traffic on sandy beaches. Coastal Mgmt, v. 35, n. 5, p. 567-583, 2007.

SCHLACHER, T. A.; THOMPSON, L.; PRICE, S. Vehicles versus conservation of invertebrates on sandy beaches: mortalities inflicted by off-road vehicles on ghost crabs. Mar. Ecol., v. 28, p. 354-367, 2007.

STEINER, A. J.; LEATHERMAN, S. P. Recreational impacts on the distribution of ghost crabs Ocypode quadrata Fab. Biol. Conserv., v. 20, p. 111-122, 1981

TURRA, A.; GONÇALVES, M. A. O ; DENADAI, M. R. Spatial distribution of the ghost crab Ocypode quadrata in low-energy tide-dominated sandy beaches. J. nat. Hist., v. 39, n. 23, p. 2163-2177, 2005.

UNDERWOOD, A. J. Experiments in ecology. Their logical design and interpretation using analysis of variance. Cambridge: Cambridge University Press, 250 p., 1997.

VELOSO, V. G.; CARDOSO, R. S.; FONSECA, D. B. Adaptações e biologia da macrofauna de praias arenosas expostas com ênfase nas espécies da região entre-marés do litoral fluminense. Oecol. Brasiliensis, v. 3, p. 121133, 1997.

WOLCOTT, T. G.; WOLCOTT, D. L. Impact of off-road vehicles on macroinvertebrates of a mid-Atlantic beach. Biol. Conserv., v. 29, p. 217-240, 1984

(Manuscript received 17 July 2008; revised 02 March 2009; accepted 24 March 2009) 